\title{
THE EFFECTS OF VAGOTOMY ON THE PHYSIOLOGY OF THE STOMACH IN PATIENTS WITH PEPTIC ULCER ${ }^{1}$
}

\author{
By JAMES S. CLARKE, EDWARD H. STORER, AND LESTER R. DRAGSTEDT \\ (From the Department of Surgery of The University of Chicago)
}

(Received for publication August 18, 1946)

Since January of 1943 bilateral section of the vagus nerves to the stomach has been performed in this clinic on 160 patients with benign duodenal, jejunal, and gastric ulcers. The technic employed to obtain complete bilateral vagus section and the clinical results have been described elsewhere (1 to 4 ). During the course of this work there arose the opportunity to study the effect of vagotomy on the continuous night secretion of gastric juice in the empty stomach, on the gastric secretory response to histamine, caffeine, insulin, and sham feeding, and on gastric motility in ulcer patients. A report dealing with a portion of these studies has appeared recently (5). The present paper presents the results of night secretion tests on 37 patients with diseases other than benign ulcers and on 42 patients who underwent vagotomy for benign ulcer. It describes the gastric secretory response to insulin hypoglycemia and sham feeding before and after vagotomy in 23 ulcer patients and the effect of vagotomy on motility in 13 such patients.

In general, the patients who underwent vagotomy and are presented here had ulcer symptoms of many years' duration. With only a few exceptions they had all experienced typical ulcer pain and in most a crater had been demonstrated by gastroduodenal $x$-ray examination. A majority had suffered pyloric obstruction, hemorrhage, or perforation. They were either refractory to medical management or had been proved unable to follow such a regime. Thus, in every case, the ulcer represented a serious affliction. The patients were led to accept vagus section because of refractory pain, recurrent hemorrhage, pyloric obstruction, or the prospect of cure of their ulcer disease without the necessity for long-term medical management.

Bilateral section of the vagus nerves to the stomach was performed at or just above the level

1 This work has been aided by grants from Mr. Andrew E. Wigeland and from the Douglas Smith Foundation for Medical Research of The University of Chicago. of the diaphragm. In those cases which required gastroenterostomy because of appreciable pyloric obstruction, the vagus section was done through the abdominal incision. In one case in this series (J. A.) a transabdominal subtotal gastrectomy and vagus section were done.

The results of this procedure have so far been extremely gratifying. In many cases $x$-ray examination has demonstrated progressive healing of large ulcers over a period of 3 to 12 weeks following operation. Prompt relief of ulcer pain following vagotomy is characteristic. All but 4 of the 42 patients reported here experienced immediate relief of all pain without recurrence. Of these 4, 2 (M. H. and J. W.) have had abdominal pain of an atypical character after vagotomy, and it is probable that this pain is not on the basis of ulcer disease. The third patient (H. K.) has had a single brief bout of epigastric distress since operation. A fourth patient continued to have symptoms after operation, and when a total gastrectomy was done elsewhere 8 months later these were determined to be due to obstruction rather than to persistent ulceration (6).

Fifteen of these 42 patients had postoperative diarrhea of varying degree, ranging from 4 to 5 loose stools per day to replacement of preoperative constipation by normal bowel habits. Actual diarrhea has not persisted longer than 3 to 6 weeks following vagotomy. In some patients the relief of preoperative habitual constipation has constituted a pleasant surprise and has persisted for months and to the present time. Postoperative pain in the thoracotomy wound has, with few exceptions, disappeared within 3 weeks following operation.

\section{METHODS}

\section{The continuous 12-hour night secretion of gastric juice}

At 9:00 p.m. the stomach was emptied with a Levine tube, or with an Ewald tube if its larger diameter was necessary. The stomach was lavaged with water until the return was clear. A Levine tube was placed in the 
stomach and was left in place under continuous Wagensteen suction for the subsequent 12 hours. Most of these patients were accustomed to intubation and the inlying Levine tube did not upset them nor interfere with their sleep. Approximately 20 per cent, those who could not rest soundly without medication, received 0.12 gram of sodium luminal at 9:00 p.m. subcutaneously. While the tube was in place the patients were not exposed to the sight, smell, or taste of food. The juice aspirated from the stomach during the night was collected at 9:00 a.m. and any specimens which contained particles of food were discarded. The volume of each specimen was measured and the free and total acid were determined in terms of "clinical units" by titration with $0.1 \mathrm{~N} \mathrm{NaOH}$ to the change of color with Topfer's reagent and phenolphthalein, respectively. The figures on night secretion in

TABLE I

The continuous night secretion of gastric juice in patients with carcinoma of the stomach

\begin{tabular}{c|c|c|c|c|c|c}
\hline \hline $\begin{array}{c}\text { Patient } \\
\text { no. }\end{array}$ & Age & $\begin{array}{c}\text { Vol- } \\
\text { ume }\end{array}$ & $\begin{array}{c}\text { Free } \\
\text { acidity, } \\
\text { clinical } \\
\text { units }\end{array}$ & $\begin{array}{c}\text { Total } \\
\text { acidity, } \\
\text { clinical } \\
\text { units }\end{array}$ & $\begin{array}{c}\text { Total } \\
\text { acid } \\
\text { output }\end{array}$ & $\begin{array}{c}\text { Volume } \\
\text { parietal } \\
\text { cell } \\
\text { output }\end{array}$ \\
\hline & & $m l$. & & & $m M$. & $\begin{array}{c}\text { ml. } \\
1\end{array}$ \\
2 & 56 & 260 & 0 & 40 & 10 & 60 \\
3 & 31 & 220 & 21 & 39 & 9 & 54 \\
4 & 74 & 84 & 0 & 44 & 4 & 24 \\
5 & 54 & 290 & 8 & 22 & 6 & 36 \\
6 & 60 & 500 & 0 & 25 & 13 & 78 \\
7 & 60 & 200 & 11 & 30 & 6 & 36 \\
8 & 60 & 290 & 0 & 38 & 11 & 66 \\
9 & 30 & 430 & 0 & 41 & 18 & 108 \\
10 & 56 & 444 & 0 & 43 & 19 & 114 \\
11 & 68 & 800 & 25 & 55 & 44 & 27 \\
12 & 64 & 400 & 17 & 30 & 12 & 72 \\
\hline Average & & 333 & 7 & 35 & 13 & 57 \\
\hline
\end{tabular}

TABLE II

The continuous night secretion of gastric juice in patients with cholelithiasis and chronic cholecystitis

\begin{tabular}{c|c|c|c|c|c|c}
\hline \hline $\begin{array}{c}\text { Patient } \\
\text { no. }\end{array}$ & Age & $\begin{array}{c}\text { Vol- } \\
\text { ume }\end{array}$ & $\begin{array}{c}\text { Free } \\
\text { acidity, } \\
\text { clinical } \\
\text { units }\end{array}$ & $\begin{array}{c}\text { Total } \\
\text { acidity, } \\
\text { clinical } \\
\text { units }\end{array}$ & $\begin{array}{c}\text { Total } \\
\text { acid } \\
\text { output }\end{array}$ & $\begin{array}{c}\text { Volume } \\
\text { parietal } \\
\text { cell } \\
\text { output }\end{array}$ \\
\hline & & $m l$. & & & $m M$. & ml. \\
1 & 27 & 630 & 13 & 31 & 20 & 120 \\
2 & 49 & 100 & 0 & 24 & 2 & 12 \\
3 & 27 & 360 & 12 & 26 & 9 & 54 \\
4 & 51 & 175 & 13 & 30 & 5 & 30 \\
5 & 45 & 445 & 0 & 27 & 12 & 72 \\
6 & 61 & 600 & 0 & 17 & 10 & 60 \\
7 & 59 & 140 & 48 & 69 & 10 & 60 \\
8 & 39 & 300 & 10 & 25 & 8 & 48 \\
9 & 49 & 260 & 24 & 53 & 14 & 64 \\
10 & 62 & 225 & 42 & 81 & 18 & 108 \\
11 & 46 & 615 & 29 & 48 & 30 & 180 \\
12 & 42 & 620 & 7 & 31 & 19 & 114 \\
13 & 53 & 200 & 32 & 55 & 11 & 66 \\
14 & 62 & 360 & 0 & 12 & 4 & 24 \\
\hline Average & & 359 & 16 & 38 & 12 & 72 \\
\hline
\end{tabular}

TABLE III

The continuous night secretion of gastric juice in patients without gastric or duodenal ulcer

\begin{tabular}{|c|c|c|c|c|c|c|c|}
\hline $\begin{array}{l}\text { Patient } \\
\text { no. }\end{array}$ & Age & Diagnosis & $\begin{array}{l}\text { Vol- } \\
\text { ume }\end{array}$ & $\begin{array}{l}\text { Free } \\
\text { acid- } \\
\text { ity- } \\
\text { clini- } \\
\text { cal } \\
\text { units }\end{array}$ & $\begin{array}{l}\text { Total } \\
\text { acid- } \\
\text { ity. } \\
\text { clini- } \\
\text { cal } \\
\text { units }\end{array}$ & $\begin{array}{l}\text { Total } \\
\text { acid } \\
\text { out- } \\
\text { put }\end{array}$ & $\begin{array}{l}\text { Vol- } \\
\text { ume } \\
\text { pari- } \\
\text { etal } \\
\text { cell } \\
\text { output }\end{array}$ \\
\hline 1 & 53 & $\begin{array}{l}\text { Common bile } \\
\text { duct stenosis }\end{array}$ & $\begin{array}{l}m l . \\
310\end{array}$ & 8 & 15 & $\underset{5}{m M}$ & $\begin{array}{r}m l . \\
30\end{array}$ \\
\hline 2 & 58 & $\mathrm{Ca}$. of rectum & 700 & 62 & 78 & 55 & 330 \\
\hline 3 & 57 & Polyp of colon & 480 & 31 & 48 & 23 & 139 \\
\hline 4 & 51 & Hernia & 330 & 13 & 27 & 9 & 54 \\
\hline 5 & 51 & $\begin{array}{l}\text { Functional } \\
\text { bowel distress }\end{array}$ & 378 & 44 & 69 & 26 & 157 \\
\hline 6 & 41 & Retroperito- & 442 & 0 & 57 & 25 & 151 \\
\hline 7 & 45 & Ca. of breast & 400 & 35 & 65 & 26 & 157 \\
\hline 8 & 37 & Endometriosis & 420 & 24 & 35 & 15 & 90 \\
\hline 9 & 16 & $\begin{array}{l}\text { Terminal } \\
\text { ileitis }\end{array}$ & 810 & 42 & 56 & 45 & 271 \\
\hline 10 & 55 & Adhesions of & 640 & 37 & 59 & 38 & 229 \\
\hline 11 & 34 & Polyp of colon & 336 & 20 & 30 & 10 & 60 \\
\hline Average & & & 477 & 29 & 49 & 25 & 152 \\
\hline
\end{tabular}

patients with diseases other than benign ulcer (Tables I to III) represent the results derived from an aspiration conducted on each patient on the night before operation. All figures on the night secretion in ulcer patients before and after operation (Tables IV to VI) represent in each case the average of 3 or more night secretion tests performed before and again within 2 weeks after operation.

It seemed valuable to express the night secretion of the stomach in terms of "Total acid output in millimoles" and "volume of parietal cell output in ml." Since the total acid concentration of the gastric juice, expressed as "clinical units," is numerically equal to the number of millimoles of $\mathrm{HCl}$ per liter in the gastric juice, the following is true.

(Total acid in C.U.) $\times$

(Vol. of night secretion in liters) $=$ (Total $\mathrm{HCl}$ output in millimoles)

Moreover, it is known that pure parietal cell secretion contains very close to $166 \mathrm{mM}$. per liter of $\mathrm{HCl}$ (7). It may therefore be said that:

$\frac{\text { (Total } \mathrm{HCl} \text { output in mM.) }}{166} \times 1,000=$

(Total $\mathrm{HCl}$ output in $\mathrm{mM}.) \times 6.02=$

(Volume of parietal cell output in $\mathrm{ml}$. ).

\section{The insulin test}

A Levine tube was inserted in the fasting stomach before breakfast and the stomach emptied. The patient lay quietly in bed in a comfortable semirecumbent position. $\mathrm{He}$ was shielded from outside stimuli, especially from food. The gastric juice was collected continuously for 
a period of approximately 2 hours. The amount aspirated in each 10-minute period was measured as to volume and free and total acidity. At the end of 30 minutes the patient received 20 or 30 units of crystalline insulin subcutaneously. Blood sugar levels were determined at $1 / 2$ hour and 2 hours after the beginning of the test. A majority of patients showed a mild insulin reaction about 1 to $1 \frac{1 / 2}{2}$ hours after receiving the injection. One or 2 insulin tests were done on each patient before and again within 2 weeks after vagotomy.

TABLE IV

The continuous 12-hour night secretion of gastric juice before and after transthoracic section of the vagus nerves to the stomach for duodenal ulcer

\begin{tabular}{|c|c|c|c|c|c|c|c|c|c|c|}
\hline \multirow[b]{2}{*}{ Patient } & \multicolumn{5}{|c|}{ Preoperative night secretion } & \multicolumn{5}{|c|}{ Postoperative night secretion } \\
\hline & Volume & $\begin{array}{l}\text { Free } \\
\text { acid } \\
\text { conc. }\end{array}$ & $\begin{array}{l}\text { Total } \\
\text { acid } \\
\text { conc. }\end{array}$ & $\begin{array}{l}\text { Total } \\
\text { acid } \\
\text { output }\end{array}$ & $\begin{array}{c}\text { Volume } \\
\text { parietal } \\
\text { cell } \\
\text { output }\end{array}$ & Volume & $\begin{array}{l}\text { Free } \\
\text { acid } \\
\text { conc. }\end{array}$ & $\begin{array}{l}\text { Total } \\
\text { acid } \\
\text { conc. }\end{array}$ & $\begin{array}{l}\text { Total } \\
\text { acid } \\
\text { output }\end{array}$ & $\begin{array}{c}\text { Volume } \\
\text { parietal } \\
\text { cell } \\
\text { output }\end{array}$ \\
\hline $\begin{array}{l}\text { 1. T.M. } \\
\text { 2. J.S. } \\
\text { 3. F. V. } \\
\text { 4. J. D. } \\
\text { 5. E. K. } \\
\text { 6. J.M. } \\
\text { 7. M. H. } \\
\text { 8. H. K. } \\
\text { 9. H. M. } \\
\text { 10. N. K. } \\
\text { 11. E. T. } \\
\text { 12. R. V. } \\
\text { 13. W.W. } \\
\text { 14. C.O. } \\
\text { 15. W. K. } \\
\text { 16. G. K. }\end{array}$ & \begin{tabular}{r}
\multicolumn{1}{c}{$m l}$. \\
1,138 \\
1,373 \\
1,029 \\
612 \\
1,193 \\
927 \\
578 \\
723 \\
775 \\
717 \\
786 \\
1,043 \\
756 \\
642 \\
1,086 \\
460
\end{tabular} & $\begin{array}{c}C . U . \\
78 \\
24 \\
61 \\
42 \\
15 \\
53 \\
25 \\
39 \\
36 \\
55 \\
44 \\
82 \\
54 \\
66 \\
46 \\
31\end{array}$ & $\begin{array}{c}C . U . \\
81 \\
47 \\
79 \\
54 \\
58 \\
68 \\
48 \\
58 \\
54 \\
81 \\
61 \\
98 \\
72 \\
81 \\
63 \\
54\end{array}$ & $\begin{array}{r}m M . \\
92 \\
65 \\
81 \\
33 \\
69 \\
63 \\
28 \\
42 \\
42 \\
58 \\
48 \\
102 \\
55 \\
52 \\
68 \\
25\end{array}$ & $\begin{array}{l}m l . \\
553 \\
373 \\
488 \\
199 \\
416 \\
378 \\
168 \\
252 \\
252 \\
349 \\
288 \\
612 \\
331 \\
313 \\
407 \\
149\end{array}$ & \begin{tabular}{r}
\multicolumn{1}{c}{$m l}$. \\
494 \\
1,065 \\
670 \\
548 \\
1,180 \\
323 \\
312 \\
65 \\
428 \\
400 \\
358 \\
486 \\
523 \\
212 \\
295 \\
248
\end{tabular} & $\begin{array}{r}C . U . \\
25 \\
36 \\
43 \\
7 \\
42 \\
9 \\
26 \\
24 \\
6 \\
19 \\
0 \\
61 \\
15 \\
2 \\
11 \\
14\end{array}$ & $\begin{array}{c}C . U . \\
37 \\
55 \\
61 \\
68 \\
81 \\
30 \\
57 \\
48 \\
44 \\
51 \\
30 \\
82 \\
56 \\
66 \\
25 \\
42\end{array}$ & $\begin{array}{c}m M . \\
18 \\
59 \\
41 \\
37 \\
95 \\
10 \\
18 \\
3 \\
19 \\
20 \\
11 \\
40 \\
29 \\
14 \\
7 \\
10\end{array}$ & $\begin{array}{r}m l . \\
108 \\
355 \\
246 \\
224 \\
575 \\
60 \\
108 \\
18 \\
114 \\
120 \\
66 \\
241 \\
175 \\
84 \\
42 \\
60\end{array}$ \\
\hline Average & 865 & 47 & 66 & 58 & 346 & 475 & 21 & 52 & 27 & 162 \\
\hline
\end{tabular}

TABLE V

The continuous 12-hour night secretion of gastric juice before and after transabdominal vagotomy plus posterior gastroenterostomy for duodenal ulcer

\begin{tabular}{|c|c|c|c|c|c|c|c|c|c|c|}
\hline \multirow[b]{2}{*}{ Patient } & \multicolumn{5}{|c|}{ Preoperative night secretion } & \multicolumn{5}{|c|}{ Postoperative night secretion } \\
\hline & Volume & $\begin{array}{l}\text { Free } \\
\text { acid } \\
\text { conc. }\end{array}$ & $\begin{array}{l}\text { Total } \\
\text { acid } \\
\text { conc. }\end{array}$ & $\begin{array}{c}\text { Total } \\
\text { acid } \\
\text { output }\end{array}$ & $\begin{array}{c}\text { Volume } \\
\text { parietal } \\
\text { cell } \\
\text { output }\end{array}$ & Volume & $\begin{array}{l}\text { Free } \\
\text { acid } \\
\text { conc. }\end{array}$ & $\begin{array}{l}\text { Total } \\
\text { acid } \\
\text { conc. }\end{array}$ & $\begin{array}{l}\text { Total } \\
\text { acid } \\
\text { output }\end{array}$ & $\begin{array}{c}\text { Volume } \\
\text { parietal } \\
\text { cell } \\
\text { output }\end{array}$ \\
\hline $\begin{array}{l}\text { 1. G.H. } \\
\text { 2. J.G. } \\
\text { 3. T. B. } \\
\text { 4. N.W. } \\
\text { 5. L. N. } \\
\text { 6. A.F. } \\
\text { 7. J.O. } \\
\text { 8. T. B. } \\
\text { 9. F.H. } \\
\text { 10. I.C. } \\
\text { 11. F.L. } \\
\text { 12. S. N. } \\
\text { 13. E. L: } \\
\text { 14. H.F. } \\
\text { 15. H.W. } \\
\text { 16. W.S. } \\
\text { 17. J.P. } \\
\text { 18. J.A. }\end{array}$ & \begin{tabular}{r}
\multicolumn{1}{c}{$m l}$. \\
1,838 \\
881 \\
1,305 \\
623 \\
998 \\
545 \\
856 \\
1,160 \\
1,095 \\
1,642 \\
755 \\
768 \\
1,053 \\
1,142 \\
1,241 \\
1,165 \\
405 \\
627
\end{tabular} & $\begin{array}{c}C . U . \\
19 \\
43 \\
33 \\
56 \\
18 \\
14 \\
62 \\
21 \\
48 \\
35 \\
60 \\
28 \\
47 \\
44 \\
32 \\
35 \\
23 \\
35\end{array}$ & $\begin{array}{c}C . U . \\
42 \\
75 \\
32 \\
56 \\
44 \\
39 \\
84 \\
39 \\
67 \\
48 \\
65 \\
38 \\
65 \\
55 \\
51 \\
52 \\
45 \\
66\end{array}$ & $\begin{array}{c}m M . \\
77 \\
66 \\
42 \\
35 \\
44 \\
21 \\
72 \\
45 \\
74 \\
79 \\
49 \\
29 \\
69 \\
63 \\
62 \\
61 \\
18 \\
41\end{array}$ & $\begin{array}{c}m l . \\
464 \\
397 \\
253 \\
210 \\
264 \\
126 \\
432 \\
271 \\
445 \\
475 \\
295 \\
175 \\
415 \\
379 \\
373 \\
367 \\
108 \\
247\end{array}$ & $\begin{array}{l}\text { ml. } \\
630 \\
663 \\
617 \\
370 \\
880 \\
602 \\
540 \\
940 \\
770 \\
910 \\
500 \\
390 \\
1,146 \\
395 \\
902 \\
893 \\
517 \\
347\end{array}$ & $\begin{array}{r}C . U . \\
0 \\
57 \\
0 \\
33 \\
50 \\
21 \\
2 \\
2 \\
0 \\
0 \\
31 \\
0 \\
34 \\
35 \\
0 \\
25 \\
14 \\
0\end{array}$ & $\begin{array}{c}C . U . \\
17 \\
83 \\
37 \\
55 \\
73 \\
32 \\
26 \\
35 \\
39 \\
16 \\
40 \\
36 \\
57 \\
44 \\
29 \\
48 \\
52 \\
57\end{array}$ & $\begin{array}{c}m M . \\
11 \\
55 \\
23 \\
20 \\
64 \\
19 \\
14 \\
33 \\
30 \\
15 \\
20 \\
14 \\
65 \\
18 \\
26 \\
43 \\
27 \\
20\end{array}$ & $\begin{array}{r}m l . \\
66 \\
331 \\
138 \\
120 \\
384 \\
116 \\
84 \\
198 \\
180 \\
90 \\
120 \\
72 \\
391 \\
108 \\
157 \\
259 \\
163 \\
120\end{array}$ \\
\hline Average & 1,000 & 36 & 54 & 53 & 317 & 665 & 17 & 43 & 29 & 172 \\
\hline
\end{tabular}


TABLE VI

The continuous 12-hour night secretion of gastric juice before and after transthoracic section of the vagus nerves to the stomach for jejunal ulcer

\begin{tabular}{|c|c|c|c|c|c|c|c|c|c|c|}
\hline \multirow[b]{2}{*}{ Patient } & \multicolumn{5}{|c|}{ Preoperative night secretion } & \multicolumn{5}{|c|}{ Postoperative night secretion } \\
\hline & Volume & $\begin{array}{l}\text { Free } \\
\text { acid } \\
\text { conc. }\end{array}$ & $\begin{array}{l}\text { Total } \\
\text { acid } \\
\text { conc. }\end{array}$ & $\begin{array}{l}\text { Total } \\
\text { acid } \\
\text { output }\end{array}$ & $\begin{array}{c}\text { Volume } \\
\text { parietal } \\
\text { cell } \\
\text { output }\end{array}$ & Volume & $\begin{array}{l}\text { Free } \\
\text { acid } \\
\text { conc. }\end{array}$ & $\begin{array}{l}\text { Total } \\
\text { acid } \\
\text { conc. }\end{array}$ & $\begin{array}{l}\text { Total } \\
\text { acid } \\
\text { output }\end{array}$ & $\begin{array}{l}\text { Volume } \\
\text { parietal } \\
\text { cell } \\
\text { output }\end{array}$ \\
\hline $\begin{array}{l}\text { 1. J. V. } \\
\text { 2. A. W. } \\
\text { 3. M. B. } \\
\text { 4. C. B. } \\
\text { 5. A. W. } \\
\text { 6. G. P. } \\
\text { 7. M.S. } \\
\text { 8. J.W. }\end{array}$ & $\begin{array}{r}\text { ml. } \\
1,020 \\
897 \\
1,021 \\
200 \\
566 \\
1,126 \\
310 \\
1,220\end{array}$ & $\begin{array}{r}C . U . \\
30 \\
41 \\
22 \\
13 \\
0 \\
12 \\
6 \\
20\end{array}$ & $\begin{array}{c}C . U . \\
43 \\
54 \\
45 \\
36 \\
21 \\
36 \\
25 \\
40\end{array}$ & $\begin{array}{c}m M . \\
44 \\
48 \\
46 \\
7 \\
12 \\
41 \\
8 \\
48\end{array}$ & $\begin{array}{r}m l . \\
265 \\
249 \\
277 \\
42 \\
62 \\
247 \\
48 \\
289\end{array}$ & $\begin{array}{l}m l . \\
286 \\
412 \\
177 \\
361 \\
233 \\
395 \\
338\end{array}$ & $\begin{array}{r}C . U . \\
0 \\
14 \\
0 \\
0 \\
0 \\
0 \\
0\end{array}$ & $\begin{array}{c}C . U . \\
25 \\
36 \\
30 \\
23 \\
19 \\
30 \\
19\end{array}$ & $\begin{array}{r}m M \\
7 \\
15 \\
5 \\
8 \\
4 \\
12 \\
6\end{array}$ & $\begin{array}{l}m l . \\
42 \\
90 \\
30 \\
42 \\
24 \\
72 \\
36\end{array}$ \\
\hline Average & 795 & 18 & 38 & 32 & 185 & 315 & 2 & 26 & 8 & 42 \\
\hline
\end{tabular}

\section{The sham meal test}

Levine tube was placed in the fasting stomach before breakfast and the stomach emptied. The patients sat up comfortably in bed and his surroundings were made as agreeable as possible. The gastric secretion was collected over three 10-minute periods as a control. Then the patient was presented with an attractively prepared, appetizing "breakfast in bed," consisting of a small glass of orange juice, 2 slices of bacon, 2 pieces of lightly buttered toast, and 1 cup of coffee with cream and sugar. The patient proceeded just as he would with any ordinary breakfast, except that after tasting and chewing it he expectorated the food into a tall container, so chosen as to prevent him from seeing the masticated food it held. The gastric secretion was collected continuously and portioned into 10 -minute samples for 1 to $1 \frac{1}{2}$ hours after the test breakfast was begun. The volume and free and total acidity of each sample were determined. If the patient swallowed any of the test breakfast, the test was discarded. The patient usually spent 10 to 15 minutes from start to finish of the test meal. One or 2 sham meal tests were done on each patient before and after vagotomy.

\section{Gastric motility}

A Miller-Abbott tube was inserted into the fasting stomach and the balloon was inflated to a pressure of 15 to 25 $\mathrm{cm}$. of water. A record of gastric motility was obtained on a smoked drum by means of a water manometer connected to this balloon. During each test the patient lay supine or on his right or left side. No medication was given to these patients during these tests, but most of them slept at least part of the time. At each test it was determined whether the patient had normal "tonus" waves and normal "hunger contraction." It was also determined whether the patient could feel and identify distention of the balloon beyond the amount used for recording and whether the passage of the contraction waves were accompanied by any sensation. The motility test was per- formed once before and again once within 2 weeks after vagus section.

\section{RESULTS}

\section{The continuous 12-hour night secretion of gas- tric juice}

It will be seen from perusal of Tables I to IV that there is a marked difference between the ulcer patients and those without benign ulcers in both quantity and acidity of juice aspirated by continuous suction during the 12 -hour nocturnal period. The average volume in 12 patients with carcinoma of the stomach was $333 \mathrm{ml}$. with a free acidity of 7 and a total of 35 clinical units. That of $14 \mathrm{pa-}$ tients with cholelithiasis was $359 \mathrm{ml}$. with a free and total acidity of 16 and 38 units. Eleven patients with miscellaneous other diseases averaged a night secretion of $477 \mathrm{ml}$. with a free acidity of 29 and a total of 49 clinical units. These figures contrast with those obtained in 42 patients with benign ulcers. The average night secretion of the 16 patients presented in Table IV, all of whom had little or no element of pyloric obstruction, was 865 $\mathrm{ml}$. with a free acid of 47 and a total of 66 clinical units. In Table $\mathrm{V}$, consisting of patients with moderate to marked pyloric obstruction, the average volume of nocturnal secretion is $1,000 \mathrm{ml}$. free acidity 36 and total 53 clinical units. Even some of the patients with jejunal ulcers following gastric resection ( $J$. V. and G. P. in Table VI) show an elevated acid output. As determined by this method the difference in acid output between pa- 
tients with benign ulcers and without is great. The exceptions to the rule are few.

Analysis of Tables IV to VI also reveals that section of the vagus nerves to the stomach, with few exceptions, causes a marked reduction in the volume and acidity of the nocturnal gastric aspiration. The average total acid output of the stomach in 16 patients (Table IV) was halved by vagotomy. Two of these patients, however (J. D. and E. K.), showed no reduction. It is not surprising that the average acidity of the aspirate was reduced after vagotomy plus gastroenterostomy (Table V), but it should be noted that the volume of aspirate was also reduced, despite regurgitation of duodenal juices through the gastroenterostomy stoma. The night secretion of all but 1 of 7 pa-

TABLE VII

Gastric secretory response of duodenal ulcer patient (F.V.) to insulin-induced hypoglycemia before and after transthoracic section of the vagus nerves to the stomach

\begin{tabular}{|c|c|c|c|c|}
\hline Time & $\begin{array}{l}\text { Vol- } \\
\text { ume }\end{array}$ & $\begin{array}{l}\text { Free } \\
\text { acid }\end{array}$ & $\begin{array}{l}\text { Total } \\
\text { acid }\end{array}$ & Remarks \\
\hline & $m l$. & C.U. & C.U. & \\
\hline
\end{tabular}

Four days before operation

\begin{tabular}{c|r|r|r|l}
\hline 8:30-8:40 a.m. & 31 & 69 & 88 & \\
$8: 50$ & 23 & 48 & 69 & \\
$9: 00$ & 24 & 51 & 70 & $9: 00 \quad$ 20 units insulin \\
$9: 10$ & 31 & 43 & 62 & given subcutaneously \\
$9: 20$ & 13 & 31 & 47 & \\
$9: 30$ & 11 & 24 & 43 & \\
$9: 40$ & 9 & 15 & 34 & \\
$9: 50$ & 19 & 8 & 27 & \\
$10: 00$ & 8 & 9 & 28 & \\
$10: 10$ & 38 & 40 & 62 & \\
$10: 20$ & 40 & 81 & 105 & \\
$10: 30$ & 33 & 107 & 130 & \\
$10: 40$ & 39 & 105 & 127 & \\
$10: 50$ & 41 & 111 & 129 & \\
$11: 00$ & 33 & 112 & 131 & \\
\end{tabular}

Eight days after operation

\begin{tabular}{c|r|r|r|l}
\hline $8: 30-8: 40$ a.m. & 45 & 44 & 56 & \\
$8: 50$ & 40 & 51 & 59 & \\
$9: 00$ & 16 & 50 & 60 & $9: 00 \quad$ 20 units insulin \\
$9: 10$ & 7 & 53 & 65 & given subcutaneously \\
$9: 20$ & 8 & 54 & 65 & \\
$9: 30$ & 7 & 45 & 62 & \\
$9: 40$ & 2 & 21 & 36 & \\
$9: 50$ & 15 & 26 & 40 & \\
$10: 00$ & 2 & 31 & 37 & \\
$10: 10$ & - & -18 & 49 & \\
$10: 20$ & 6 & 38 & 49 & \\
$10: 30$ & 2 & 39 & 53 & \\
$10: 40$ & 5 & 26 & 40 & \\
$10: 50$ & 5 & 20 & 37 & \\
\hline
\end{tabular}

TABLE VIII

Gastric secretory response of duodenal ulcer patient (J.O.) to insulin-induced hypoglycemia before and after transabdominal vagotomy plus posterior gastroenterostomy

\begin{tabular}{|c|c|c|c|c|}
\hline Time & $\begin{array}{l}\text { Vol- } \\
\text { ume }\end{array}$ & $\begin{array}{l}\text { Free } \\
\text { acid }\end{array}$ & $\begin{array}{l}\text { Total } \\
\text { acid }\end{array}$ & Remarks \\
\hline & $m l$. & C.U. & C.U. & \\
\hline
\end{tabular}

Three days before operation

\begin{tabular}{c|r|r|r|r}
\hline 8:00-8:10 a.m. & 58 & 90 & 101 & \multicolumn{2}{|c}{} \\
$8: 20$ & 28 & 86 & 97 & $8: 30 \quad$ Fasting blood sugar \\
$8: 30$ & 56 & 75 & 95 & 52 mgm. per cent \\
$8: 40$ & 27 & 85 & 95 & $8: 30 \quad 30$ units insulin \\
$8: 50$ & 40 & 83 & 97 & given subcutaneously \\
$9: 00$ & 36 & 65 & 80 & \\
$9: 10$ & 26 & 54 & 70 & \\
$9: 20$ & 4 & 70 & 85 & \\
$9: 30$ & 36 & 93 & 112 & $9: 30 \quad$ Feels hot and hands \\
$9: 40$ & 40 & 95 & 113 & and feet are numb. \\
$9: 50$ & 42 & 113 & 132 & Flushed. Slight tremor \\
$10: 00$ & 42 & 124 & 136 & $10: 00$ Blood sugar 20 \\
$10: 10$ & 25 & 124 & 136 & mgm. per cent \\
$10: 20$ & 25 & 113 & 129 & \multicolumn{2}{|c}{} \\
$10: 30$ & 25 & 110 & 129 & \\
\hline
\end{tabular}

Twelve days after operation

\begin{tabular}{c|r|r|r|c}
\hline $8: 00-8: 10$ a.m. & 3 & 6 & 17 & \\
$8: 20$ & 12 & 0 & 13 & $8: 30 \quad$ Fasting blood sugar \\
$8: 30$ & 10 & 0 & 11 & 76 mgm. per cent \\
$8: 40$ & 10 & 0 & 12 & 8:30 30 units insulin \\
$8: 50$ & 12 & 0 & 17 & given subcutaneously \\
$9: 00$ & 18 & 0 & 9 & \\
$9: 10$ & 17 & 0 & 12 & \\
$9: 20$ & 17 & 0 & 11 & \\
$9: 30$ & 8 & 0 & 12 & \\
$9: 40$ & 15 & 0 & 20 & \\
$9: 50$ & 8 & 0 & 10 & \\
$10: 00$ & 8 & 0 & 16 & \\
$10: 10$ & 10 & 0 & 15 & $10: 00$ Blood sugar 44 \\
$10: 20$ & 9 & 0 & 15 & mgm. per cent. Feels \\
$10: 30$ & 8 & 0 & 12 & weak \\
\hline
\end{tabular}

tients with jejunal ulcers (Table VI) was also reduced after vagotomy.

\section{The insulin test}

The protocols of representative insulin tests are presented in Tables VII to IX. There was no consistent response to insulin hypoglycemia in terms of volume of 10 -minute secretions. There was, however, a regular response in terms of acidity of the aspirate following the injection of insulin. Beginning 60 to 90 minutes following injection, there was usually a marked rise in free and total acidity of the aspirated juice. In reviewing this series of tests it appeared that there was a random variation of the acidities of the samples that amounted to approximately 20 clinical units in 
TABLE IX

Gastric secretory response of duodenal ulcer patient (G. H.) to insulin-induced hypoglycemia before and after transabdominal vagotomy plus posterior gastroenterostomy

\begin{tabular}{l|l|l|l|l}
\hline Time & $\begin{array}{l}\text { Vol- } \\
\text { ume }\end{array}$ \\
\hline$m l$. & $\begin{array}{c}\text { Free } \\
\text { acid }\end{array}$ & $\begin{array}{c}\text { Total } \\
\text { acid }\end{array}$ \\
C.U.
\end{tabular} \mid \begin{tabular}{l} 
C.U. \\
\hline
\end{tabular}

Three days before operation

\begin{tabular}{c|r|r|r|ll}
\hline 7:20-7:30 a.m. & 20 & 0 & 16 & $7: 30$ & 20 units insulin \\
$7: 40$ & 30 & 0 & 14 & given subcutaneously \\
$7: 50$ & 22 & 0 & 17 & & \\
$8: 00$ & 15 & 0 & 21 & & \\
$8: 10$ & 10 & 0 & 20 & & \\
$8: 20$ & 8 & 0 & 15 & & \\
$8: 30$ & 50 & 17 & 40 & & \\
$8: 40$ & 64 & 39 & 56 & $8: 40 \quad$ Feels hungry and \\
$8: 50$ & 39 & 55 & 70 & listless \\
$9: 00$ & 60 & 55 & 69 & 8:50 & Blood sugar 14 \\
$9: 10$ & 60 & 48 & 59 & mgm. per cent \\
$9: 20$ & 62 & 60 & 72 & $9: 00$ Feels weak \\
$9: 30$ & 53 & 42 & 58 & & \\
\hline
\end{tabular}

Ten days after operation

\begin{tabular}{|c|c|c|c|c|}
\hline $\begin{array}{c}\text { 7:00-7:10 a.m. } \\
7: 20 \\
7: 30 \\
7: 40 \\
7: 50 \\
8: 00 \\
8: 10 \\
8: 20 \\
8: 30 \\
8: 40 \\
8: 50 \\
9: 00 \\
9: 10 \\
9: 20 \\
9: 30\end{array}$ & $\begin{array}{r}6 \\
8 \\
3 \\
4 \\
14 \\
7 \\
2 \\
1 \\
6 \\
4 \\
4 \\
1 \\
1 \\
1 \\
1\end{array}$ & $\begin{array}{l}\mathbf{0} \\
0 \\
\mathbf{0} \\
\mathbf{0} \\
\mathbf{0} \\
\mathbf{0} \\
\mathbf{0} \\
\mathbf{0} \\
\mathbf{0} \\
\mathbf{0} \\
\mathbf{0} \\
\mathbf{0} \\
\mathbf{0} \\
\mathbf{0} \\
\mathbf{0}\end{array}$ & $\begin{array}{r}12 \\
6 \\
9 \\
9 \\
6 \\
6 \\
10 \\
8 \\
9 \\
21 \\
8 \\
8 \\
14 \\
9 \\
9 \\
17 \\
15\end{array}$ & $\begin{array}{l}\text { 7:30 Fasting blood sugar } \\
71 \text { mgm. per cent } \\
7: 30 \quad 20 \text { units insulin } \\
\text { given subcutaneously }\end{array}$ \\
\hline
\end{tabular}

some cases. Therefore, it was arbitrarily decided to call the response positive only in those cases in which the total acidity increased following insulin administration by more than 20 clinical units over its control values. Using this criterion, 5 of the 22 ulcer patients tested failed to respond preoperatively by increased acidity of the gastric aspirate to 1 or 2 insulin tests. Following vagotomy; 18 of 21 patients tested failed to respond. No patient who failed to respond before operation gave a positive response after operation.

\section{The sham meal test}

The protocols of representative sham meal tests are presented in Tables X to XII. Here again the volumes of the 10 -minute samples were so variable that they were considered to be meaningless.
Typically a marked increase in the free and total acidity of the gastric aspirate began within 10 to 20 minutes of the mastication of the sham meal and continued for over an hour. Again it was decided to designate a response as positive if the total acidity increased by 20 clinical units or more over its control value. Fifteen of 20 ulcer patients tested before operation gave a positive response to the sham meal. Following vagotomy only 2 of 22 patients tested gave a positive response. All patients who failed to respond to the sham meal before operation also failed to respond postoperatively.

\section{Gastric motility}

Thirteen of the 23 ulcer patients whose response to insulin and the sham meal are reported in this paper underwent a gastric motility test before and after vagotomy. The results were much the same in every case. Two representative tracings are presented in Figures 1 and 2. All 13 patients

TABLE $X$

Gastric secretory response of duodenal ulcer patient (T.M.) to sham meal before and after transthoracic section of the vagus nerves to the stomach

\begin{tabular}{|c|c|c|c|c|}
\hline Time & $\begin{array}{l}\text { Vol- } \\
\text { ume }\end{array}$ & $\begin{array}{l}\text { Free } \\
\text { acid }\end{array}$ & $\begin{array}{l}\text { Total } \\
\text { acid }\end{array}$ & Remarks \\
\hline & $m l$. & C.U. & C.U. & \\
\hline \multicolumn{5}{|c|}{ Six days before operation } \\
\hline $\begin{array}{c}\text { 7:30-7:40 a.m. } \\
7: 50 \\
8: 00 \\
8: 10 \\
8: 20 \\
8: 30 \\
8: 40 \\
8: 50 \\
9: 00 \\
9: 10 \\
9: 20 \\
9: 30\end{array}$ & $\begin{array}{r}4 \\
14 \\
2 \\
25 \\
20 \\
18 \\
13 \\
13 \\
19 \\
7 \\
19 \\
9\end{array}$ & $\begin{array}{r}67 \\
69 \\
29 \\
46 \\
97 \\
76 \\
100 \\
102 \\
98 \\
92 \\
85 \\
69\end{array}$ & $\begin{array}{r}84 \\
84 \\
45 \\
63 \\
111 \\
93 \\
114 \\
117 \\
113 \\
109 \\
100 \\
87\end{array}$ & $\begin{array}{l}\text { 8:00 Sham meal begun } \\
\text { 8:20 Sham meal com- } \\
\text { pleted }\end{array}$ \\
\hline
\end{tabular}

Ten days after operation

\begin{tabular}{|c|c|c|c|c|}
\hline $\begin{array}{c}\text { 7:00-7:10 a.m. } \\
7: 20 \\
7: 30 \\
7: 40 \\
7: 50 \\
8: 00 \\
8: 10 \\
8: 20 \\
8: 30 \\
8: 40 \\
8: 50 \\
9: 00\end{array}$ & $\begin{array}{r}7 \\
14 \\
12 \\
11 \\
4 \\
9 \\
2 \\
12 \\
8 \\
2 \\
8 \\
7\end{array}$ & $\begin{array}{l}19 \\
27 \\
25 \\
22 \\
28 \\
18 \\
30 \\
28 \\
21 \\
28 \\
25 \\
21\end{array}$ & $\begin{array}{l}42 \\
51 \\
56 \\
57 \\
66 \\
60 \\
54 \\
53 \\
53 \\
58 \\
58 \\
58\end{array}$ & $\begin{array}{l}7: 20 \text { Sham meal begun } \\
7: 40 \text { Sham meal com- } \\
\text { pleted }\end{array}$ \\
\hline
\end{tabular}


TABLE XI

Gastric secretory response of duodenal ulcer patient (I. C.) to sham meal before and after transabdominal section of the vagus nerves plus posterior gastroenterostomy

\begin{tabular}{|c|c|c|c|c|}
\hline Time & $\begin{array}{l}\text { Vol- } \\
\text { ume }\end{array}$ & $\begin{array}{l}\text { Free } \\
\text { acid }\end{array}$ & $\begin{array}{l}\text { Total } \\
\text { acid }\end{array}$ & Remarks \\
\hline & $m l$ & C.U. & C.U. & \\
\hline
\end{tabular}

Two days before operation

\begin{tabular}{c|r|r|r|l}
\hline $8: 00-8: 10$ a.m. & 18 & 0 & 14 & \\
$8: 20$ & 21 & 14 & 38 & \\
$8: 30$ & 21 & 49 & 60 & $8: 30$ Sham meal begun \\
$8: 40$ & 30 & 70 & 80 & $8: 40$ Sham meal com- \\
$8: 50$ & 60 & 80 & 102 & pleted \\
$9: 00$ & 40 & 97 & 105 & \\
$9: 10$ & 20 & 70 & 94 & \\
$9: 20$ & 27 & 63 & 71 & \\
$9: 30$ & 20 & 74 & 85 & \\
$9: 40$ & 20 & 68 & 80 & \\
$9: 50$ & 20 & 67 & 80 & \\
$10: 00$ & 32 & 58 & 62 & \\
\hline
\end{tabular}

Seven days after operation

\begin{tabular}{c|r|r|r|ll}
\hline 8:00-8:10 a.m. & 8 & 8 & 33 & & \\
$8: 20$ & 5 & 8 & 27 & & \\
$8: 30$ & 6 & 15 & 31 & & \\
$8: 40$ & 7 & 14 & 29 & & \\
$8: 50$ & 6 & 0 & 24 & & \\
$9: 00$ & 7 & 10 & 25 & $9: 00$ & Sham meal begun \\
$9: 10$ & 11 & 0 & 30 & $9: 10$ & Sham meal ended \\
$9: 20$ & 7 & 5 & 34 & & \\
$9: 30$ & 5 & 19 & 38 & & All samples bile \\
$9: 40$ & 4 & 20 & 38 & & stained \\
$9: 50$ & 10 & 0 & 30 & & \\
$10: 00$ & 9 & 5 & 32 & & \\
\hline
\end{tabular}

tested showed a basal "tonus" rhythm with a frequency of 2 to 3 per minute (wave duration of 20 to 30 seconds). This was unaltered by vagotomy.

All 13 also showed larger "hunger contraction" waves, as described by Carlson (8), sometimes coming irregularly and sometimes in series, each wave having a duration of roughly 60 seconds. In 12 of these 13 patients these hunger contractions were absent 10 to 14 days following vagus section. In the other patient ( J. G.) they were present, but much weaker and more irregular than before operation. The preoperative hunger contraction waves were stronger and more frequent in patients whose ulcers were complicated by a degree of pyloric obstruction than in those without obstruction. There is evidence that these hunger contractions return within several months following vagotomy. They were present and normal in appearance in the case of J. G., when tested 3 months following vagotomy. Another patient
(N. W.) had no such waves 10 days following transthoracic vagotomy, but had normal contraction waves 8 days following. posterior gastroenterostomy for pyloric obstruction $1 \frac{1}{2}$ months later. A third patient (N. K.) had normal rushes of hunger contractions 11 months following transthoracic vagotomy.

In all patients tested, distention of the stomach by the inlying balloon was felt as a vague epigastric pressure or gas pain, and there was no appreciable difference in the quality of the sensation nor its threshold after vagotomy. Five of the 13 patients upon whom motility studies were done were sufficiently introspective accurately to identify preoperatively the hunger contraction waves, describing the sensation as a "pulling in the stomach," a "feeling of suction," and as "hunger pangs." Within the first 2 weeks following vagotomy none of these had sufficiently good contraction

TABLE XII

Gastric secretory response of duodenal ulcer patient (J.A.) to sham meal before and after transabdominal section of the vagus nerves plus subtotal gastric resection

\begin{tabular}{|c|c|c|c|c|}
\hline \multirow[t]{2}{*}{ Time } & $\begin{array}{l}\text { Vol- } \\
\text { ume }\end{array}$ & $\begin{array}{l}\text { Free } \\
\text { acid }\end{array}$ & $\begin{array}{l}\text { Total } \\
\text { acid }\end{array}$ & Remarks \\
\hline & $m l$. & C.U. & C.U. & \\
\hline \multicolumn{5}{|c|}{ Eleven days before operation } \\
\hline $\begin{array}{c}\text { 8:00-8:10 a.m. } \\
8: 20 \\
8: 30 \\
8: 40 \\
8: 50 \\
9: 00 \\
9: 10 \\
9: 20 \\
9: 30 \\
9: 40 \\
9: 50\end{array}$ & $\begin{array}{r}34 \\
28 \\
11 \\
10 \\
7 \\
13 \\
8 \\
9 \\
23 \\
15 \\
42\end{array}$ & $\begin{array}{r}0 \\
22 \\
41 \\
17 \\
20 \\
0 \\
33 \\
55 \\
60 \\
56 \\
45\end{array}$ & $\begin{array}{r}11 \\
39 \\
74 \\
69 \\
65 \\
49 \\
92 \\
109 \\
98 \\
88 \\
78\end{array}$ & $\begin{array}{l}8: 20 \text { Sham meal begun } \\
\text { 8:45 Sham meal com- } \\
\text { pleted }\end{array}$ \\
\hline
\end{tabular}

Twelve days after operation

\begin{tabular}{c|r|l|l|ll}
\hline $7: 30-7: 40$ a.m. & 5 & 0 & 38 & & \\
$7: 50$ & 25 & 0 & 26 & & \\
$8: 00$ & 5 & 0 & 17 & $8: 00 \quad$ Sham meal begun \\
$8: 10$ & 11 & 0 & 23 & & \\
$8: 20$ & 9 & 0 & 33 & $8: 20 \quad$ Sham meal com- \\
$8: 30$ & 6 & 0 & 27 & pleted \\
$8: 40$ & 13 & 0 & 24 & \\
$8: 50$ & 6 & 0 & 17 & & \\
$9: 00$ & 4 & 0 & 19 & & \\
$9: 10$ & 10 & 0 & 18 & & \\
$9: 20$ & 6 & 0 & 15 & & \\
$9: 30$ & 5 & 0 & 19 & \\
$9: 40$ & 2 & 0 & 15 & \\
$9: 50$ & 6 & 0 & 17 & \\
$10: 00$ & 20 & 0 & 23 & \\
\hline
\end{tabular}




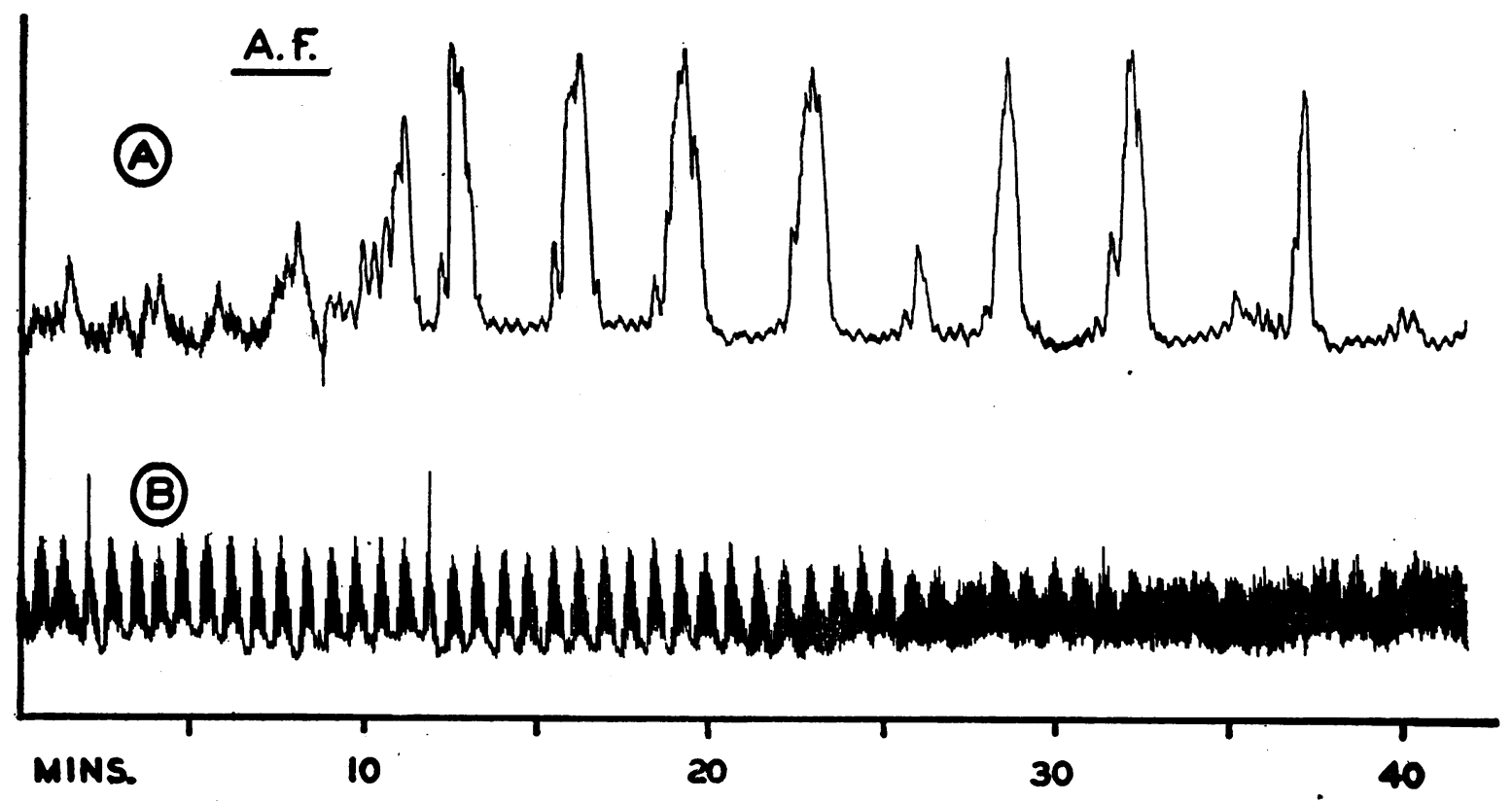

Fig. 1. Tracings Showing the Motility of the Fasting Stomach of a Patient (A. F.) with a Duodenal Ulcer 2 Days Before (A) and 8 Days After (B) Subdiaphragmatic Vagotomy Plus Posterior GastroenterOSTOMY

waves to give a fair test for postoperative sensation of this sort.

\section{DISCUSSION}

During the past 3 years the results of section of the vagus nerves for refractory peptic ulcer have been excellent, both in our hands and those of others $(4,5,9)$. Ulcer pain has been absent following vagotomy, but the fact that in a few instances it has occurred briefly makes it unlikely that pain of this sort is mediated via the vagi. Several of our patients (J. G. and N. W.) have suffered rather marked gastric retention following vagotomy, as evidenced by distention, belching of foul gas, and anorexia, and as determined by $x$-ray examination. This was relieved after gastroenterostomy. In several other patients milder symptoms of this sort, present during the first 2 to 4 weeks following vagotomy, have cleared spontaneously without any additional operative procedure. The initial hypomotility of the stomach after vagotomy will combine with pyloric obstruction, in cases where it is present, to produce decreased gastric emptying. As a result, it is necessary to combine vagus section with gastroenterostomy in cases which show an appreciable amount of pyloric obstruction before operation. It is also imperative to keep an indwelling suction tube in the stomach for the first 2 to 4 days after vagotomy to prevent distention and possible acute dilatation of the atonic viscus.

The postoperative tendency toward loose bowels, which has been an unexpected feature in the postoperative course of 15 of the 42 patients presented here, remains unexplained. On theoretical grounds, parasympathetic denervation of the gastrointestinal tract down to the mid-colon would seem more likely to result in constipation.

The operation of vagus section for peptic ulcers is predicated upon the theory that an abnormally increased interdigestive secretion of gastric acid and possibly pepsin, mediated by impulses proceeding down the vagus nerves, is a major factor in the pathogenesis of such ulcers. Cushing in 1932 (10) reported a group of cases in which lesions in the midbrain resulted in fatal ulceration of the upper gastrointestinal tract. Under experimental conditions typical peptic ulcers can be produced by artificially induced hypersecretion of gastric juice (11) and by permitting the gastric juice to act on the intestinal mucosa without being neutralized by duodenal secretions ( 12 to 14$)$. It 

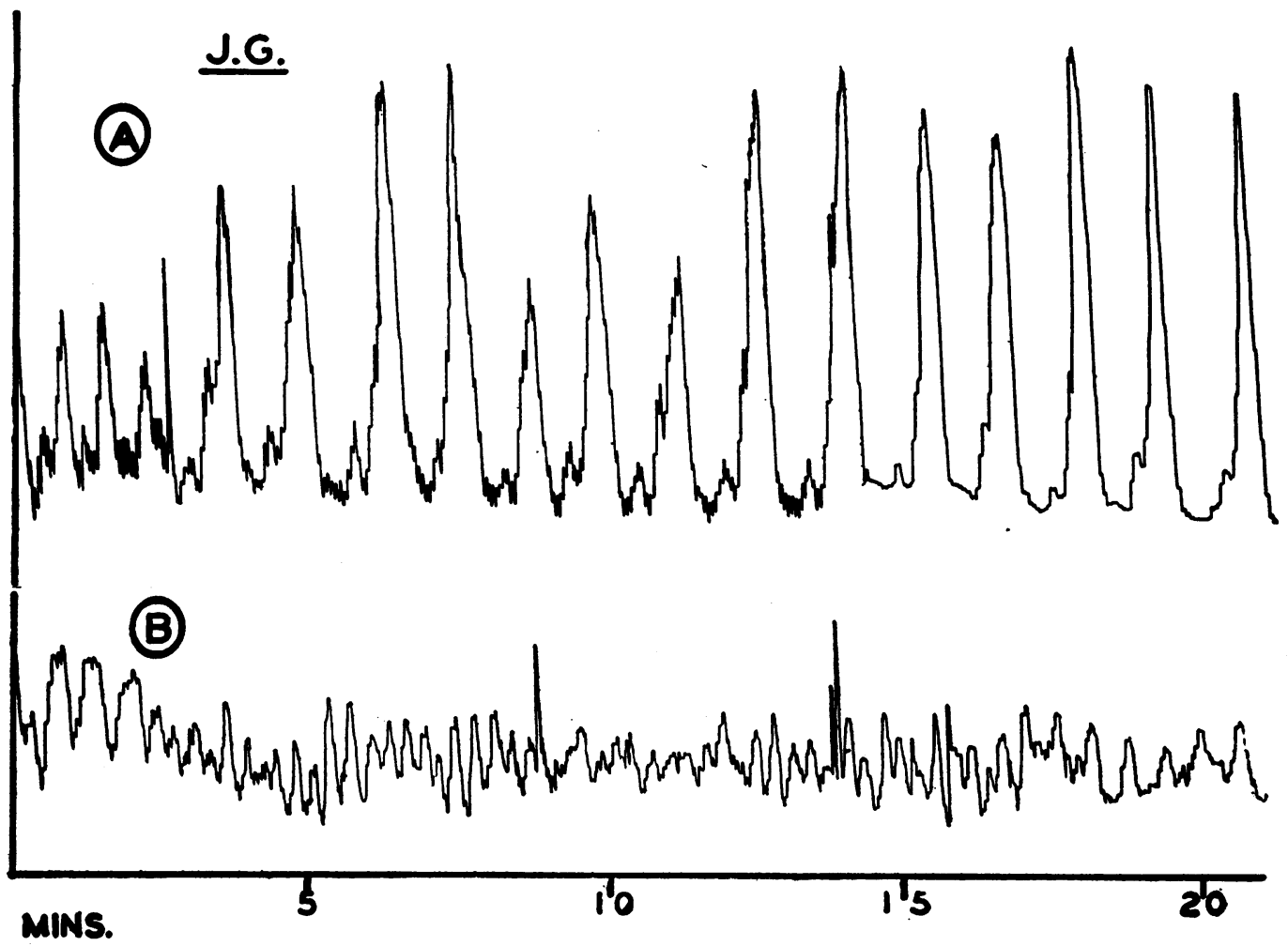

Fig. 2. Tracings Showing the Motility of the Fasting Stomach of a Patient (J. G.) with a Duodenal Ulcer 1 Day Before (A) and 9 Days After (B) Subdiaphragmatic Section of the Vagus Nerves to the Stomach

is therefore important to determine whether or not ulcer patients do have an abnormally increased interdigestive gastric secretion and whether their secretion is reduced following section of the vagus nerves. The continuous nocturnal gastric aspirations reported here represent an effort to answer these questions.

Night secretion tests on patients as performed by the technic described in this paper have their limitations and must be interpreted cautiously. Great care must be taken to ensure that the Levine tube does not become plugged or kinked in the stomach during the night, resulting in a volume of aspirate less than would be obtained under ideal conditions. There is a consistent alteration in character of the aspirate following vagotomy, in that it becomes more mucoid in nature. The increased viscosity may tend to reduce the volume of juice aspirated below its correct value.

There is an inevitable amount of regurgitation of duodenal juice into the stomach in most cases, probably more marked in those patients. with gas- troenterostomies or gastric resections. This might be expected to alter somewhat the volume of aspirate but should not alter the calculated total $\mathrm{HCl}$ output. There is also undoubtedly some loss of gastric juice through the pylorus and this should be decreased in the presence of pyloric obstruction. On comparing Tables IV and V it may be seen that the actual volumes obtained in 18 cases with pyloric obstruction were somewhat elevated above those obtained in 16 cases without appreciable obstruction, but that the free and total acidities were not greatly different in the two groups. Finally, it must be recognized that the non-ulcer patients considered in Tables I to III do not constitute an ideal control group because of the presence of pathology other than ulcer.

Despite these limitations the results summarized in Tables I to VI are sufficiently consistent and the differences sufficiently great to state unequivocally that the continuous night secretion of gastric juice was markedly greater in the ulcer patients than in those without ulcers, both in volume and acidity. 
This is particularly emphasized if the calculated total acid output or volume of parietal cell secretion is considered. These conclusions are at variance with those of Sandweiss et al (15) whose studies caused them to conclude that the "nocturnal volume of gastric juice in patients with duodenal ulcer (as obtained by continuous suction) is on the average not greater than that of normal subjects of the same age and sex." However, their patients experienced only mild ulcer distress and their ulcer disease was neither so active, so prolonged, so refractory to medical management, nor subject to so many complications as the disease in our series. Even so, they did note hypersecretion of $\mathrm{HCl}$ in several of their ulcer patients, and these were, interestingly enough, patients presenting more or less intractable ulcers clinically. In our experience interdigestive gastric secretion studies have constituted a logical and satisfying corroboration to the excellent clinical results of vagus section.

The insulin test was proposed by Ihre (16), Babkin (17), and Hollander (18) as a method of investigating the integrity and function of the vagus nerves to the stomach. Gastric secretion is stimulated as a result of the hypoglycemia induced by insulin $(19,20)$ and this response is abolished by vagus section $(21,22)$. In the tests presented in this paper the increase in acidity of the gastric juice occurred at roughly the same time as the maximum fall in blood sugar. In a study of 17 ulcer patients, Thornton, Storer and Dragstedt (5) found that 15 gave a positive response to insulin hypoglycemia before vagotomy and that only 1 of these responded after vagotomy. The results obtained in the present group of 23 additional ulcer patients are roughly the same, a few failing to respond in 1 or 2 insulin tests before operation. Three of our patients gave a definite positive response following operation. A fourth (J. G.), though showing a negative response 2 weeks following vagus section, had a positive response to both the insulin and sham meal test 3 months following vagotomy. It should be noted that all of these 4 patients underwent vagotomy via the abdominal route, a technically more difficult approach to obtain complete bilateral vagus section than through the thorax. Their postoperative response to insulin may be indicative of residual vagus innervation of the stomach. Another patient (N.
$\mathrm{K}$.), on the other hand, still showed a negative response to insulin 11 months after vagotomy. We were unable to note any appreciable difference in the response to insulin between our ulcer patients and 6 normal young adults tested in the same manner.

The sham meal test elicits a gastric response which is likewise dependent upon an intact vagal innervation of the stomach. Pavlov showed in dogs (23) that the gastric secretory response to sham feeding and to conditioned reflexes is abolished by vagus section. Necheles and Maskin (24) studied the response of normal and ulcer patients to sham feeding and found little difference between the two groups. A previous attempt on a group of 10 of our patients (5) yielded positive responses before operation in only 3 cases, after operation in none.

Some care must be taken in performing the sham meal test if best results are to be obtained. The inlying Levine tube is naturally distracting to the patient. Positive results were obtained much more consistently in those ulcer patients who had had long experience with gastric intubation than in those unused to the procedure. A positive response was often obtained on a second test, when it had been absent on the first. It is probable that a positive response could finally be obtained in almost every patient if a sufficient numbr of tests were done. Every effort must be made to present the patient with an appetizing sham meal and to shield him from the sight of the expectorated food. If the patient swallows at all during the test, the test is invalidated due to the stimulating effect on secretion of the food itself in the stomach. The response to the sham meal constitutes a conditioned as well as an unconditioned reflex, and psychic inhibition of the normal response occurs easily.

Out of the 20 patients upon whom sham meal tests were done before vagotomy and whose data are summarized in Table XIII, 15, gave a positive response to at least one of 1 or 2 sham meal tests. Following vagotomy, only 2 of 22 gave positive responses. This again may represent residual vagus innervation to the stomach in these cases. The sham meal test and the insulin test appear to be about equally reliable criteria of the integrity of the vagi, and they supplement each other in a useful manner. 
TABLE XIII

The secretory response of the stomach to insulin hypoglycemia and to sham feeding before and after section of the vagus nerves to the stomach in patients with duodenal ulcers

\begin{tabular}{|c|c|c|c|c|c|}
\hline Patient & Operation & $\begin{array}{c}\text { Preop. } \\
\text { response } \\
\text { to } \\
\text { insulin }\end{array}$ & $\begin{array}{c}\text { Postop. } \\
\text { response } \\
\text { to } \\
\text { insulin }\end{array}$ & $\begin{array}{c}\text { Preop. } \\
\text { response } \\
\text { to } \\
\text { sham } \\
\text { meal }\end{array}$ & $\begin{array}{l}\text { Postop. } \\
\text { response } \\
\text { to } \\
\text { sham } \\
\text { meal }\end{array}$ \\
\hline 1. T. M. & $\begin{array}{l}\text { Transthoracic } \\
\text { vagotomy }\end{array}$ & + & - & + & - \\
\hline 2. J.S. & $\begin{array}{l}\text { Transthoracic } \\
\text { vagotomy }\end{array}$ & - & - & & \\
\hline 3. F. V. & $\begin{array}{l}\text { Transthoracic } \\
\text { vagotomy }\end{array}$ & + & - & + & - \\
\hline 4. J.D. & $\begin{array}{l}\text { Transthoracic } \\
\text { vagotomy }\end{array}$ & + & - & + & - \\
\hline 5. E. K. & $\begin{array}{l}\text { Transthoracic } \\
\text { vagotomy }\end{array}$ & - & - & - & - \\
\hline 6. J.M. & $\begin{array}{l}\text { Transthoracic } \\
\text { vagotomy }\end{array}$ & + & - & - & - \\
\hline 7. M. H. & $\begin{array}{l}\text { Transabd. } \\
\text { vagotomy }\end{array}$ & + & + & + & + \\
\hline 8. J. V. & $\begin{array}{l}\text { Transth. vag. } \\
\text { (jejunal ulcer) }\end{array}$ & + & & + & - \\
\hline 9. A. W. & $\begin{array}{l}\text { Transth. vag. } \\
\text { (jejunal ulcer) }\end{array}$ & + & - & + & - \\
\hline 10. G. H. & $\begin{array}{l}\text { Transabd. vag. } \\
\text { plus PGE }\end{array}$ & + & - & $t$ & - \\
\hline 11. J.G. & $\begin{array}{l}\text { Transabd. vag. } \\
\text { plus PGE }\end{array}$ & + & - & + & - \\
\hline 12. T. B. & $\begin{array}{l}\text { Transabd. vag. } \\
\text { plus PGE }\end{array}$ & + & - & - & - \\
\hline 13. N.W. & $\begin{array}{l}\text { Transabd. vag. } \\
\text { plus PGE }\end{array}$ & + & - & + & - \\
\hline 14. L. N. & $\begin{array}{l}\text { Transabd. vag. } \\
\text { plus PGE }\end{array}$ & + & + & & - \\
\hline 15. A.F. & $\begin{array}{l}\text { Transabd. vag. } \\
\text { plus PGE }\end{array}$ & - & - & + & + \\
\hline 16. J.O. & $\begin{array}{l}\text { Transabd. vag. } \\
\text { plus PGE }\end{array}$ & + & - & - & - \\
\hline 17. T. B. & $\begin{array}{l}\text { Transabd vag. } \\
\text { plus PGE }\end{array}$ & & - & & - \\
\hline 18. F. H. & $\begin{array}{l}\text { Transabd vag. } \\
\text { plus PGE }\end{array}$ & + & - & + & - \\
\hline 19. I. C. & $\begin{array}{l}\text { Transabd. vag. } \\
\text { plus PGE }\end{array}$ & + & - & + & - \\
\hline 20. F. L. & $\begin{array}{l}\text { Transabd. vag. } \\
\text { plus PGE }\end{array}$ & - & & + & - \\
\hline 21. S. N. & $\begin{array}{l}\text { Transabd. vag. } \\
\text { plus PGE }\end{array}$ & + & - & + & - \\
\hline 22. E. L. & $\begin{array}{l}\text { Transabd. vag. } \\
\text { plus PGE }\end{array}$ & + & + & - & - \\
\hline 23. J.A. & $\begin{array}{l}\text { Transabd. vag., } \\
\text { gastric resec- } \\
\text { tion }\end{array}$ & - & - & + & - \\
\hline
\end{tabular}

Note: Results recorded above are derived from 1 or 2 tests of each sort performed before operation and repeated within 2 weeks after operation.

The gastric secretory response to insulin and the sham meal are thus mediated via the vagus nerves, should be absent after complete vagotomy, and is to be sharply differentiated from the response to histamine and caffeine which has been shown (5) to be little altered by vagotomy.

The results presented here regarding gastric motility and sensation in 13 ulcer patients subjected to vagotomy agree with those obtained previously in this clinic in a study of 8 earlier cases and are in accordance with the findings of Moore et al (9). Vagus section does not seem to impair the sensation resulting from gastric distention, nor the sensations of nausea and appetite. Ulcer pain can be felt following vagotomy. We have not yet been able to determine whether typical hunger pang sensations that can be correlated with gastric hunger contractions persist following vagus section.

\section{SUM MARY}

1. The continuous night secretion of gastric juice in the empty stomach of patients with benign ulcer is, as a rule, greater in volume and acidity than that of patients without such ulcers. It is usually markedly reduced following section of the vagus nerves to the stomach.

2. The secretory response of the fasting stomach of patients with benign ulcer to the stimulation of insulin hypoglycemia and of a sham meal is abolished by vagus section.

3. The motility of the empty stomach of patients with benign ulcer is, as a rule, markedly reduced for at least 2 weeks following section of the vagus nerves to the stomach. It returns toward normal limits within a period of 1 to 3 months.

4. Following section of the vagus nerves to the stomach, our ulcer patients have shown healing of their ulcers on x-ray examination and, with rare exceptions, they have experienced immediate and persistent relief from ulcer pain and freedom from subsequent development of hemorrhage, perforation, or pyloric stenosis.

\section{BIBLIOGRAPHY}

1. Dragstedt, L. R., and Owens, F. M., Jr., Supradiaphragmatic section of vagus nerves in treatment of duodenal ulcer. Proc. Soc. Exper. Biol. and Med., 1943, 53, 152.

2. Dragstedt, L. R., Palmer, W. L., Schafer, P. W., and Hodges, P. C., Supra-diaphragmatic section of the vagus nerves in the treatment of duodenal and gastric ulcers. Gastroenterology, 1944, 3, 450.

3. Dragstedt, L. R., and Schafer, P. W., Removal of the vagus innervation of the stomach in gastroduodenal ulcer. Surgery, 1945, 17, 742.

4. Dragstedt, L. R., Vagotomy for gastroduodenal ulcer. Ann. Surg., 1945, 122, 973.

5. Thornton, T. F., Jr., Storer, E. H., and Dragstedt, L. R., Supradiaphragmatic section of the vagus 
nerves; effect on gastric secretion and motility in patients with peptic ulcer. J. A. M. A., 1946, 130, 764.

6. Cole, W., Personal communication.

7. Hollander, F., and Cowgill, G. R., Studies in gastric secretion. I. Gastric juice of constant acidity. J. Biol. Chem., 1931, 91, 151.

8. Carlson, A. J., The Control of Hunger in Health and Disease. University of Chicago Press, Chicago, 1916.

9. Moore, F. D., Chapman, W. P., Schulz, M. D., and Jones, C. M., Trans-diaphragmatic resection of the vagus nerves for peptic ulcer. New England J. Med., 1946, 234, 241.

10. Cushing, H., Peptic ulcers and interbrain. Surg., Gynec., and Obst., 1932, 55, 1.

11. Hay, L. J., Varco, R. L., Code, C. F., and Wangensteen, O. H., Experimental production of gastric and duodenal ulcers in laboratory animals by intramuscular injection of histamine in beeswax. Surg., Gynec., and Obst., 1942, 75, 170.

12. Mann., F. C., and Williamson, C. S., Experimental production of peptic ulcer. Ann. Surg., 1923, 77, 409.

13. Matthews, W. B., and Dragstedt, L. R., Etiology of gastric and duodenal ulcer; experimental studies. Surg., Gynec., and Obst., 1932, 55, $265^{\circ}$.

14. Elman, R., and Hartmann, A. F., Spontaneous peptic ulcers of duodenum after continued loss of total pancreatic juice. Arch. Surg., 1931, 23, 1030.
15. Sandweiss, D. J., Sugarman, M. H., Podolsky, H. M., and Friedman, M. H. F., Nocturnal gastric secretion in duodenal ulcer. J. A. M. A., 1946, 130, 258.

16. Ihre, B. J. E., Human Gastric Secretion. Oxford University Press, London, 1939.

17. Babkin, B. P., Secretory Mechanism of the Digestive Glands. Paul B. Hoeber, Inc., New York, 1944.

18. Hollander, F., In discussion of paper on vagus section for ulcers. Gastroenterology, 1944, 3, 466.

19. Roholm, K., Clinical investigations into effect of intravenous injection; gastric secretion in normal individuals. Acta med. Scandinav., 1930, 73, 472.

20. Kalk, H., and Meyer, P. F., Blutzuckerspiegel und Magensekretion. Ztschr. f. klin. Med., 1932, 120, 692.

21. La Barre, J., and de Cespédès, C., Les variations de le sécrétion gastrique au cours de l'hypoglycémie insulinique. Compt. rend. Soc. de biol., 1931, 106, 480.

22. Okada, S., Kuramochi, K., Tsukahara, T., and Ooinoue, $T$., Pancreatic function: humoroneural regulation of gastric, pancreatic and biliary secretions. Arch. Int. Med., 1929, 43, 446.

23. Pavlov, I. P., The Work of the Digestive Glands. Charles Griffen, London, 1910.

24. Necheles, H., and Maskin, M. H., Studies on constitution and peptic ulcer; appetite secretion in normal persons and in ulcer patients. Am. J. Digest. Dis. and Nutrition, 1936, 3, 90. 